\title{
A Cautionary Note on Amphibole Geobarometry ${ }^{\dagger}$
}

\author{
José F. Molina ${ }^{1, *}$, Aitor Cambeses ${ }^{1}$, Juan A. Moreno ${ }^{2}$, Irene Morales ${ }^{1}$, Concepción Lázaro ${ }^{1}$, Pilar Montero ${ }^{1}$ \\ and Fernando Bea ${ }^{1}$
}

Citation: Molina, J.F.; Cambeses, A.; Moreno, J.A.; Morales, I.; Lázaro, C.; Montero, P.; Bea, F. A Cautionary Note on Amphibole Geobarometry. Environ. Sci. Proc. 2021, 6, 17. https://doi.org/10.3390/iecms202109346

Academic Editor: Paul Sylvester

Published: 25 February 2021

Publisher's Note: MDPI stays neutral with regard to jurisdictional claims in published maps and institutional affiliations.

Copyright: (C) 2021 by the authors. Licensee MDPI, Basel, Switzerland. This article is an open access article distributed under the terms and conditions of the Creative Commons Attribution (CC BY) license (http://creativecommons.org/licenses/by/4.0/)
1 Department of Mineralogy and Petrology, University of Granada, 18010 Granada, Spain; aitorc@ugr.es (A.C.); iremoral@ugr.es (I.M.); clazaro@ugr.es (C.L.); pmontero@ugr.es (P.M.); fbea@ugr.es (F.B.)

2 CICTERRA, CONICET, Universidad Nacional de Córdoba, Córdoba X5016CGA, Argentina; jmoreno_2@ugr.es

* Correspondence: jfmolina@ugr.es

+ Presented at the 2nd International Electronic Conference on Mineral Science, 1-15 March 2021; Available online: https://iecms2021.sciforum.net/.

The classical Al-in-hornblende barometer has been very successful in determining the depth of intrusion of the metaluminous cordilleran granitoid plutons that bear the buffering assemblage at near solidus conditions: hornblende-biotite-plagioclase-orthoclase-quartzsphene-two Fe-Ti-oxides (or one Fe-Ti oxide + epidote)-melt-vapor (e.g., [1-3]).

Ridolfi et al. [4] and Ridolfi and Renzulli [5] derived empirical amphibole-only barometric expressions that could be potentially applied to a larger number of phenocrystic assemblages from volcanic rocks. However, Erdmann et al. [6] claimed that these barometers are inaccurate and can give untenable estimates.

A graphical barometer based on the partitioning of $\mathrm{Al}$ and Si between amphibole and plagioclase was derived by Fershtater [7] using amphibole-plagioclase compositional pairs of rocks from the Urals. More recently, Molina et al. [8] calibrated an empirical expression based on experimental data that can be applied to igneous and high-grade metamorphic rocks.

In order to compare the reliability of amphibole-only and amphibole-plagioclase barometry, in this work, we test the performance of the expressions of Ridolfi and Renzulli [5] and Molina et al. [8], using an experimental data set compiled from the literature that has been recently published by Molina et al. [9].

In accordance with Erdmann et al. [6], the test reveals unsustainable pressure estimates with the amphibole-only barometric expressions from Ridolfi and Renzulli [5]. In contrast, the amphibole-plagioclase barometer from Molina et al. [8] performs well and yields a precision better than $1.7 \mathrm{kbar}$ for the Qz-Amp-Pl and Ol-free-Cpx-Amp-Pl assemblages, with the amphibole compositions having $>1$ apfu (23O; normalization to 13-CNK) Al, 0.05-0.27 apfu Ti, and $<1.07$ apfu $\mathrm{Fe}^{3+}$.

Supplementary Materials: The supplementary file is available online at https://www.mdpi.com/article/10.3390/iecms2021-09346.

Institutional Review Board Statement: Not applicable.

Informed Consent Statement: Not applicable.

Data Availability Statement: Not applicable. 


\section{References}

1. Hammarstrom, J.M.; Zen, E. Aluminum in hornblende: an empirical igneous geobarometer. Am. Mineral. 1986, 71, 1297-1313.

2. Schmidt, M.W. Amphibole composition in tonalite as a function of pressure: an experimental calibration of the Al-in-hornblende barometer. Contrib. Mineral. Petrol. 1992, 110, 304-310.

3. Anderson, J.L.; Smith, D.R. The effects of temperature and $\mathrm{fO}_{2}$ on the Al-in-hornblende barometer. Am. Mineral. 1995, 80, 549449.

4. Ridolfi, F.; Renzulli, A.; Puerini, M. Stability and chemical equilibrium of amphibole in calc-alkaline magmas: an overview, new thermobarometric formulations and application to subduction-related volcanoes. Contrib. Mineral. Petrol. 2010, 160, 45-66.

5. Ridolfi, F.; Renzulli, A. Calcic amphiboles in calc-alkaline and alkaline magmas: thermobarometric and chemometric empirical equations valid up to $1130^{\circ} \mathrm{C}$ and $2.2 \mathrm{GPa}$. Contrib. Mineral. Petrol. 2012, 163, 877-895.

6. Erdmann, S.; Martel, C.; Pichavant, M.; Kushnir, A. Amphibole as an archivist of mag- matic crystallization conditions: problems, potential, and implications for inferring magma storage prior to the paroxysmal 2010 eruption of Mount Merapi, Indonesia. Contrib. Mineral. Petrol. 2014, 167, 1016.

7. Fershtater, G.B. Empirical hornblende-plagioclase geobarometer. Geokhimiya 1990, 3, 328-335.

8. Molina, J.F.; Moreno, J.A.; Castro, A.; Rodríguez, C.; Fershtater, G.B. Calcic amphibole thermobarometry in metamorphic and igneous rocks: New calibrations based on plagioclase/amphibole Al-Si partitioning and amphibole/liquid Mg partitioning. Lithos 2015, 232, 286-305.

9. Molina, J.F.; Cambeses, A.; Moreno, J.A.; Morales, I.; Montero, P.; Bea, F. A reassessment of the amphibole-plagioclase NaSi$\mathrm{CaAl}$ exchange thermometer with applications to igneous rocks. Am. Mineral. 2021, 106, 782-800. 